\title{
Rumah Belajar as Online Learning Model for Early Childhood Education
}

\author{
Vebby Julianti Permata ${ }^{1, *}$, Heny Dhoehaeni ${ }^{2}$ \\ ${ }^{1,2}$ School of Postgraduate Early Childhood Education, Universitas Pendidikan Indonesia, Bandung, Indonesia. \\ *Corresponding author. Email: vebbyjp@upi.edu.
}

\begin{abstract}
Covid-19 pandemic has a significant impact on various sectors, including the education sector. To break the spread of Covid-19, social distancing must be done. The government sets a learning at home policy to prevent children from interactions that will have an impact on their health. On the other hand, educational services must continue to run even in a pandemic situation like this. Thus, we need an online learning model that supports children's activities while at home. Portal Rumah Belajar is one alternative online learning model that can be used by students, including early childhood. This study aims to describe the use of the Portal Rumah Belajar as one of the online learning models whose existence is very relevant to the current situation. This study uses qualitative research methods with a type of phenomenology. The sampling technique used in the study is purposive sampling through interviews with Early Childhood teachers. The results of this study are expected to provide information on the use of Portal Rumah Belajar as an alternative to online learning models during the Covid-19 pandemic.
\end{abstract}

Keywords: Early childhood, learn from home, online learning.

\section{INTRODUCTION}

Since March 2nd, 2020, the Indonesian Government has reported 2 cases of Coronavirus Disease (Covid-19) and it is increasing rapidly every day. In order to deal with the impact of the Covid-19 Pandemic, on March 13rd, 2020, the Government of Indonesia through Presidential Decree Number 7, 2020, formed a Covid-19 Handling Agency, called the Task Force for the Acceleration of Handling Coronavirus President [1]. One of its duties is to accelerate the handling of Covid19. The Covid-19 Task Force was ordered by the President to immediately synergize with 12 elements in government in overcoming the Covid-19 Pandemic in Indonesia.

With this synergy, the Ministry of Education and Culture immediately responded by implementing three policies regulation to prevent Covid-19 in the Education and Implementing Education Policies in the Covid-19 Pandemic Emergency which contained directions on the learning process from home [2]. The policy was made to protect all school residents from the Covid-19 Pandemic. It applies to all levels of education, including Early Childhood Education (PAUD). Even though learning is carried out from home, teachers are obliged to guide and monitor the students' learning process by Distance Learning (DL) and teachers have to visit the students' homes while still applying the health protocols determined by the Indonesian Ministry of Health [3].

Learning from Home Activities (LFH) for the education level are based on circular letter number 4 , 2020 , emphasizes that the learning process is carried out from home through distance learning (DL) which is implemented to provide meaningful learning experiences for students [4]. Studying at home can be focused on life skills education, including the Covid-19 Pandemic and this is strengthened by Circular letter number 15, 2020 [5].

In preschool education, the implementation of distance learning needs a full cooperation between teachers and parents. Because when learning from home, the teacher plays rules in planning and assessing the child's development, while the parents at home are implementing the learning process in giving educational simulations for children's growth and development. In other words, parents are teachers' partners during online learning [6]. Distance Learning (PJJ) for students at the preschool level (PAUD) is carried out offline and online by utilizing the internet network in the learning process through applications, such as: Google Classroom, Zoom, WhatsApp and Rumah Belajar to add repertoire of knowledge and a variety of learning activities. 
Previous research that has examined the use of Rumah Belajar applications in student learning is conducted by Hasan Chabibie and Wildan Hakim with the title: "The Effect of Technology Acceptance with Web Usability: A Case Study of the Kemendikbud Rumah Belajar Portal" [7]. The study aims to determine how teachers and students accept internet technology for online or online learning when accessing Rumah Belajar in class [7]. Therefore, in this research, the author focuses more on the use of Rumah Belajar in online learning during the pandemic era in a kindergarten (call it TK PH) in Central Java.

\section{METHOD}

In this research, the author used phenomenological research methodology and data will be described descriptively. According to Husserl in Wimpenny and Gass, phenomenology aims to reveal a developing object or phenomenon with its meaning [8]. In line with this, Smith also revealed that phenomenology is a study of phenomena that explains the appearance of something, things that arise from experience, or how to get experience [9]. This means that phenomenology defines what is contained in an experience. In this case, the research analyses the learning experience during the pandemic period with an online learning model through interviews to explore more in-depth information about the use of Rumah Belajar during online learning during the BDR period with its obstacles in TK PH.

\section{RESULT AND DISCUSSION}

\subsection{Online Learning}

The social distancing, physical distancing and PSBB policies in several areas is one of steps applied by the government to reduce the current spread of the CoronaVirus, because the COVID-19 pandemic has a very significant impact on various sectors including education. Therefore, the Online learning mode is considered appropriate for now. In line with this, Rekkedal [10], Volery and Lord [11] revealed that online learning is access to learning experiences through the use of several technologies [12]. According to Plt. PAUD Dikdasmen Kemendikbud PJJ is divided into two types, namely learning online (online) and learning outside the network (offline) [13]. Online learning is intended for Indonesians who are able to use internetbased remote interaction models, such as using the Google Classroom application, Zoom, WhatsApp and Rumah Belajar which refers to Circular Number 4 of 2020 [4]. In online learning or learning from home (LFH), the use of Rumah Belajar Portal can be an alternative distance learning (DL) media that can be used by teachers and parents. It is in line with Istamia's [14] statement that Rumah Belajar Portal is an attractive alternative to online learning media in Indonesia [14].
This is the reason why kindergartens in Central Java use Rumah Belajar when studying from home or online learning.

The Portal Rumah Belajar is one of the e-learning (online) media that can be used for various facilities [14]. Portal Rumah Belajar also contains content and learning media for all levels of education which are presented in its features. It has 8 main features, namely Learning Resources, BSE (Electronic School Book), Question Bank, Virtual Laboratory, Cultural Map, Space Exploration Vehicle, PKB/Online Education and Training, Virtual Class and 3 additional features namely, Community Work, Teacher Work and Language Literary Work [14]. Through the Rumah Belajar portal, teachers and students can access interactive learning material, simulations and interactions between educational communities [14]. The portal itself is used by TK PH teachers during online learning by downloading learning video content on the learning resource feature that contained in the portal. After downloading, the teacher sends the learning video to the WhatsApp group so the learning material can be conveyed to students as explained by one of the teachers. Scalar variables and physical constants should be italicized, and a bold (non-italics) font should be used for vectors and matrices. Do not italicize subscripts unless they are variables. Equations should be either displayed (with a number in parentheses) or inline. Use the built-in Equation Editor or MathType to insert complex equations.

Yes, due to the conditions of learning from home (LFH) we use Rumah Belajar as an alternative so that the children are not bored and they are happy... the teacher uses the portal by downloading the learning video and then sending it back to the parent's WhatsApp group... (quote from IM interview).

The teachers found that Rumah Belajar portal is easy to access that makes them more interested and choose it as an alternative to online learning. Then the teachers can choose the learning content contained in the learning resource feature that has previously been adjusted to the learning plan. In the learning resources feature, there are several choices of learning content, such as audio content, video content and web content that can be used by them. Furthermore, the teachers can download and send everything they need to children via the WhatsApp group as explained in the following interview quote:

Before implementing online learning the school prepares pre-activities such as compiling a simple lesson plan, making learning videos, or downloading appropriate learning videos from Rumah Belajar. Then the learning videos are sent through the whatsapp group for children's learning activities from home. Parents accompany children and send 
documentation of learning activities through the WhatsApp group ... (IM interview quote).

The teachers utilize the Rumah Belajar as an online learning model so that children feel happy and not bored as in the interview quote above. The presence of teachers during the Covid-19 pandemic must be a solution in helping parents carry out the burden of the learning process at home easily. Children's learning during the Covid 19 pandemic become an additional burden for parents by providing assignment activities as if the teacher is shifting his duties to the parents. Even though in Circular No. 15 of 2020 concerning Learning from Home guidelines, children's learning activities are in the form of fun life skills to maintain children's mental and physical health [15]. In the online implementation at TK PH, teachers usually use Rumah Belajar twice in a week that is on Tuesday and Thursday.

Rumah Belajar is used as an online alternative for movement activities and songs as well as fairy tales which are usually scheduled every Tuesday and Thursday (Quote from YR interview).

The use of Rumah Belajar in twice meeting a week is still lacking time, because there is still lots of video or audio learning content that teachers can download for other aspects of child development. Because the learning content in Rumah Belajar is very relevant to the 2013 curriculum [16]. Furthermore, Istamia also states that Rumah Belajar as an online learning medium facilitates teachers and students to get learning content related with school syllabus [14]. In addition, there are still many features on the portal that can be used by teachers, such as virtual classes, cultural maps, space exploration vehicles and others.

A very attractive appearance especially for early childhood, easy to understand and follow. makes Rumah Belajar is the online learning model that is chosen by TK PH teachers. Because basically early childhood learning must be meaningful and fun according to the principles of PAUD learning, and video learning is a form of media that can be used to convey learning in a fun and meaningful way [17]. The use of Rumah Belajar also helps develop children's good character, such as being honest, patient, helpful and others through fairy tale videos.

Cultivating character valuesneeds to be given to children from an early age, in their golden age through habituals and examples. As Syarbini's expression that the implementation of character education in PAUD is educating through habitual [18]. The inculcation of character education valueswill be meaningful if these valuescan be implemented in everyday life. Therefore, the valuesof character education emphasize more on children's habits to do positive things and the examples/ examples displayed by the teacher [19]. The use of
Rumah Belajar helps teachers to set good examples in early childhood during the Covid-19 pandemic.

\subsection{Online Learning Constraints}

During today's pandemic, the government sets the learning process to be distance learning or known as LFH (Learning from Home). Online-based distance learning (DL) during the Covid-19 Pandemic was actually a solution for teachers in carrying out their duties, although it did not always go as expected. The teacher is an important part of learning, because the teacher must be able to change the teaching and learning process which is usually face-to-face into online. Of course, this is a big challenge, especially for ECE teachers because they must be able to master technology. In online learning, not only teachers and technology media are important, but the role of parents is also an important part. For PAUD units, students aged 4-6 years have not been able to learn online independently. Here lies the challenge for the school to work together with parents. This is because parents, apart from being a companion, also act as implementers of programs that have been assigned by the teacher for children's activities at home. According to Mattekawang in Kurniati, et al the orientation of education in Indonesia still focuses on academic development by putting aside other developments [6]. Therefore, as an innovation and increase in the diversity of activities for children's growth and development, Rumah Belajar can be the right choice for online learning.

Yes, children like to learn from home with Rumah Belajar, besides being able to develop character, children also get another general knowledge. (Quote from IM interview)

Synergy itself is not enough to be a solution in implementing distance learning (DL), this is because many parents are constrained by their IT skills, apart from being constrained by internet access and internet credit constraints. As stated by Agustin, et al. [20], the obstacles that are often experienced by teachers or parents when learning online are costs and difficulties in using technology. Therefore, teachers carry out learning activities from home online through the WhatsApp Group. Through the WhatsApp Group the teacher sends learning content downloaded from Rumah Belajar as explained in the previous interview quote. Although initially the school hopes that parents can use the portal directly because of its easy to use.

The same as other schools, the obstacles in online or online learning such as internet networks, quotas and moreover not all parents can use gadgets/cell phones, this is because they do not have sophisticated gadget/cell phones. (YR interview quote) 
Based on the observations of the teachers of TK PH from April 62020 to April 11 2020, it is known that there are obstacles in online learning with the use of Rumah Belajar, both when downloading learning videos and reporting learning results. It can be seen that on the first day there were $77.78 \%$, the second day $83.33 \%$, the third day $77.78 \%$, the fourth day $83.33 \%$, and the fifth day $72.2 \%$ of parents experienced problems during online learning. This means that there are $8 \%$ of parents who experience problems with the internet network due to their domicile and living environment with an unstable internet network. Furthermore, there are 7\% of parents having problems with pulses or data packages. It is obviously clear that the pandemic has an impact on all human life, especially the economy. During this pandemic, many parents had to be sent home, not to mention the salary that had to be cut because of that. There are even some parents who have to be willing to be laid off at work. This is what causes parents to be constrained by buying credit or data packages. In addition, the economic condition of the family also causes an impact on $7 \%$ of parents who are constrained by unsupportive devices/cell phones. This is supported by Galusha that distance learning by utilizing technology or online has obstacles or obstacles such as the availability of connectivity funds, internet problems, and inadequate communication facilities [21].

\section{CONCLUSION}

Based on the results of the research, it shows that the COVID-19 pandemic has an impact on teaching and learning activities that must switch to online or online learning. So, the use of Rumah Belajar as an online learning model is welcomed by parents because it is considered as the most appropriate during the pandemic. Parents and teachers are helped by using Rumah Belajar. Instead of having various features, it also has fun content and educational requirements, especially in developing students' good character during the pandemic. The use of Rumah Belajar as a medium of liaison between the school and parents in delivering learning materials sent by the teacher via the WhatsApp Group on a scheduled basis. There are obstacles faced in online learning with the use of Rumah Belajar, namely the role of teachers and parents, including: $8 \%$ of parents have internet network problems, $7 \%$ of parents are constrained by data packages, and the remaining $7 \%$ are constrained by devices/cell phones.

\section{REFERENCES}

[1] Presidential Decree Number 7 of 2020 about the Task Force for the Acceleration of Handling Covid 19 [Internet]. Jakarta; 2020. Available from: www.surialaw.com/news/artikel-covid-19-coronavirus-disease-keputusan-presiden-nomor-7-tahun2020-tentang-gugus-tugas-percepatan-penanganan- corona-virus-disease-2019-covid-19-dankeputusan-presiden-republik-indonesia-nomor-9tahun-2020-tentang-perubahan-atas-keputusanpresiden.

[2] Ministry of Education and Culture of the Republic Indonesia. Edaran tentang pencegahan wabah COVID-19 di lingkungan satuan pendidikan seluruh Indonesia [Internet]. Jakarta; 2020. Available from: https://www.kemdikbud.go.id/ main/blog/2020/03/sikapi-covid19-kemendikbudterbitkan-dua-surat-edaran.

[3] Arifa FN. Tantangan pelaksanaan kebijakan belajar dari rumah dalam masa darurat Covid-19. Info singkat: Kajian singkat terhadap isu aktual dan strategis. Jurnal Bidang Kesejahteraan Sosial. 2020;7(1):13-18.

[4] Ministry of Education and Culture of the Republic Indonesia. Surat Edaran tentang Pelaksanaan Kebijakan Pendidikan dalam Masa Darurat Penyebaran Covid-19 [Internet]. Jakarta: Kemdikbud; 2020. Available from: http://www.kemdikbud.go.id /main/blog/2020/03/se-mendikbud-pelaksaankebijakan-pendidikan-dalam-masa-daruratpenyebaran-covid-19.

[5] Ministry of Education and Culture of the Republic Indonesia. Surat Edaran tentang Pedoman Penyelenggaraan Belajar dari Rumah dalam Masa Darurat Penyebaran Covid-19 [Internet]. Jakarta: Kemdikbud; 2020. Available from: http://www.kemdikbud.go.id/main/blog/2020/05/se -sesjen-pedoman-penyelenggaraan-belajar-darirumah-dalam-masa-darurat-penyebaran-covid-19.

[6] Kurniati E, Alfaeni DK, Andriani F. Analisis peran orang tua dalam mendampingi anak di masa pandemi Covid-19. Jurnal Obsesi: Jurnal Pendidikan Anak Usia Dini. 2020;5(1):241-256. DOI: $10.31004 /$ obsesi.v5i1.541.

[7] Chabibie MH, Hakim W. Pengaruh penerimaan teknologi dengan kebergunaan web. Ultimacomm: Jurnal Ilmu Komunikasi. 2016;8(1):37-59.

[8] Wimpenny P, Gass J. Interviewing in phenomenology and grounded theory: Is there a difference? Journal of Advanced Nursing. 2000;31(6):1485-92. DOI:10.1046/j.1365-2648.20 00.01431.x.

[9] Smith, DW. The (Stanford) encyclopedia of philosophy-phenomenology. Stanford: Metaphysics Research Lab; 2018.

[10]Rekkedal T, Qvist-Eriksen S, Keegan D, Súilleabháin GÓ, Coughlan R, Fritsch H. Internet based e-learning, pedagogy and support systems. Norway: NKI Distance Education; 2003.

[11] Volery T, Lord D. Critical success factors in online education. International Journal of Educational 
Management. 2000;14(5):216-23. Available from: https://doi.org/10.1108/09513540010344731.

[12] Moore JL, Dickson-Deane C, Galyen K. E-learning, online learning, and distance learning environments: Are they the same? Internet and Higher Education. 2011;14(2):129-35.

[13]Prodjo WA. Belajar jarak jauh bukan pembelajaran online, begini penjelasannya [Internet]. Jakarta: Kompas.com; 2020 [Cited 2020 Juli 07]. Available from:https://www.kompas.com/edu/read/2020/06/1 6/200131471/pembelajaran-jarak-jauhbukanpembelajaran-daring-inipenjelasannya.

[14] Istamia PY. Making use of 'Rumah Belajar portal' to improve students' ability to read descriptive. Journal of English Education and Teaching. 2019;3(2):127-42.

[15] Susilawati E. Analisis dampak program diklat Online TIK guru Pustekkom terhadap aksesbilitas konten pembelajaran pada fitur Rumah Belajar. Jurnal Pendidikan. 2018;19(2):84-103.

[16]Laila F, Utama ID, Wisudariani NM. Pemanfaatan portal/web e-learning pada mata pelajaran bahasa Indonesia di SMA Negeri 4 Singaraja. Jurnal Pendidikan Bahasa dan Sastra Indonesia Universitas Pendidikan Ganesha. 2019;9(1):13-22. Available from: http://dx.doi. org/10.23887/ jjpbs.v9i1.20263.

[17]Bakri F, Rhodiyah A, Nurindrasari M, Pratiwi S, Muliyati D. The design of physics learning video as joyful-based learning media enrichment by powtoon. In Seminar Nasional Fisika (SNF) Universitas Negri Surabaya. 2020 Mar 1;1491(1):15.

[18] Kurniasaih ER, Suliyem S, Wulandari S. Teacher strategies in character education development in kindergarten. Indonesian Journal of Early Childhood Education Studies. 2014;3(2):94-101.

[19] Cahyaningrum ES, Sudaryanti S, Purwanto NA. Pengembangan nilai-nilai karakter anak usia dini melalui pembiasaan dan keteladanan. Jurnal Pendidikan Anak. 2017;6(2):203-13.

[20] Agustin M, Puspita RD, Nurinten D, Nafiqoh H. Tipikal kendala guru PAUD dalam mengajar pada masa pandemi Covid-19 dan implikasinya. Jurnal Obsesi: Jurnal Pendidikan Anak Usia Dini. 2020;5(1):334-45. DOI: 10.1016/j.childyouth. 2020.105440.

[21]Galusha JM. Barriers to learning in distance education. Hattiesburg: University of Southern Mississippi; 1998. 